\title{
Performance Comparison of Different Hole Transport Layer Configurations in a Perovskite-based Solar Cell using SCAPS-1D Simulation
}

\author{
S. Reza Hosseini ${ }^{1}$, Nagihan Delibaş ${ }^{2 *}$, Mahsa Bahramgour ${ }^{3}$, Alireza Tabatabaei Mashayekh ${ }^{4}$, Aligholi Niaei ${ }^{5}$ \\ ${ }^{1}$ University of Tabriz, Department of Chemical Engineering and Petroleum, Tabriz, Iran, (ORCID: 0000-0002-0946-7489), sr.hosseini.sr@gmail.com \\ ${ }^{2}$ University of Sakarya, Faculty of Art \& Science, Department of Physics, Sakarya, Turkey, (ORCID: 0000-0001-5752-062X), caylak@sakarya.edu.tr \\ ${ }^{3}$ University of Tabriz, Department of Chemical Engineering and Petroleum, Tabriz, Iran, (ORCID: 0000-0002-2925-1538), m_bahramgur@outlook.com \\ ${ }^{4}$ School of Industrial and Information Engineering, Automation and Control Engineering, Milano, Italy, (ORCID: 0000-0002-4295-0923), \\ seyedalireza.tabatabaei@mail.polimi.it \\ 5 University of Tabriz, Department of Chemical Engineering and Petroleum, Tabriz, Iran, (ORCID: 0000-0001-5580-4266), aniaei@tabrizu.ac.ir
}

(First received 15 June 2021 and in final form 20 December 2021)

(DOI: 10.31590 /ejosat.951602)

ATIF/REFERENCE: Hosseini, S.R., Delibas, N., Bahramgour, M., Mashayekh, A. \& Niaei, A (2021). Performance Comparison of Different Hole Transport Layer Configurations in a Perovskite-based Solar Cell using SCAPS-1D Simulation. European Journal of Science and Technology, (31), 121-126.

\begin{abstract}
Due to the solar cell industry, environmentally friendly and low-cost electricity generation processes, the use of non-renewable energy sources, especially fossil fuels, is developing day by day. Among the different solar cells under use, perovskite solar cells have recently experienced rapid growth in research due to their high performance and low production costs at the same time. Perovskite solar cells typically consist of some main layers such as absorbent, carrier layers and electrodes. The hole transport layer (HTL) is very important in the perovskite solar cell structure due to its important role in cell performance. The light absorbed by the perovskite layer leads to the formation of electrons and holes. These load carriers are then transported to the electrodes by the electron and hole transport layers. There are several types of HTL, such as small molecules in the cell structure, polymeric and inorganic HTLs. In addition, these different options can be in various configurations such as tandem, composite and single structures. In this study, three common HTL types, SpiroOMeTAD, P3HT and $\mathrm{Cu}_{2} \mathrm{O}$, were studied and their effects on cell performance in different composite, tandem and single forms were investigated and their results were compared. These comparisons were made in the simulation environment in SCAPS-1D software. The final results showed approximately the best $27 \%$ efficiency of the use of tandem structure in the HTL configuration with SpiroOMeTAD and P3HT in the special perovskite solar cell created in this study.
\end{abstract}

Keywords: Tandem, composite, perovskite solar cell, HTL, SCAPS-1D.

\section{SCAPS-1D Simülasyonu Kullanılarak Perovskit Tabanlı Güneş Pilinde Farklı Delik Aktarım Katmanı Konfigürasyonlarının Performans Karşılaştırması}

$\ddot{\mathbf{O} z}$

Güneş pili endüstrisi, çevre dostu ve düşük maliyetli elektrik üretim süreçleri nedeniyle, yenilenemeyen enerji kaynaklarının özellikle fosil yakıtların yerine, kullanımı her geçen gün artmaktadır. Aynı zamanda bilinen farklı güneş pilleri arasındaki perovskit güneş pilleri ile yapılan araştırmalarda yüksek performansları ve düşük üretim maliyetleri sebebiyle hızlı bir büyüme yaşanmıştır. Perovskit güneş pilleri tipik olarak; emici, taşıyıcı katmanlar ve elektrotlar gibi bazı ana katmanlardan oluşur. Hücre performansındaki önemli rolü nedeniyle delik taşıma tabakası (HTL), perovskit güneş pili yapısında çok önemlidir. Perovskit tabakası tarafından emilen 1şık, elektron ve deliklerin oluşumuna yol açar. Bu yük taşıyıcıları daha sonra elektron ve delik taşıma katmanları ile elektrotlara taşınır. Hücre yapısındaki küçük moleküller, polimerik ve inorganik HTL'ler gibi çeşitli HTL türleri vardır. Ayrıca bu farklı seçenekler, tek yapılı, tandem ve kompozit gibi çeşitli konfigürasyonlarda olabilir. $\mathrm{Bu}$ çalışmada, üç yaygın HTL tipi, Spiro-OMeTAD, P3HT ve Cu $2 \mathrm{O}$ oluşturulmuş, bunların farklı kompozit, tandem ve tek formlardaki hücre performansı üzerindeki etkileri araştırılmış olup sonuçları karşılaştırılmıştır. Bu karşılaştırmalar SCAPS-1D yazılımındaki simülasyon ortamında yapılmıştır. Nihai sonuçlar, bu çalışmada oluşturulan özel perovskit güneş pilinde HTL tipi, Spiro-OMeTAD ve P3HT konfigürasyonundaki tandem yapı kullanımın yaklaşık $\% 27$ ile en iyi verimlilik olduğunu göstermiştir. 


\section{Introduction}

Energy sources and energy generation are always global issues around the world research industry. From the perspective of finite and infinite sources, energies generally divide into two common nonrenewable and renewable energies, respectively. In recent years, because of nonrenewable energies like fossil fuel finishing sources, trends have moved to researches about renewable sources like wind and solar energies. Due to the advantages like the infinite source of sunlight and its generality and environmental friendliness, solar cells have become suitable electricity generation devices. Besides, their fabrication costs are lower than other nonrenewable sources. Silicon solar cells were the first developed generation of solar cells that represented good efficiencies. Silicon solar cells' high fabrication costs led to developing new solar cell generations with other materials representing high efficiencies and low costs. Perovskite solar cells are a new type of solar cells that were developed recently because of their good properties like their tunable bandgaps, low fabrication costs, and high efficiencies.

Perovskite solar cells generally consist of several layers. Like all of the solar cells, the mechanism of electricity generation in these cells is the same but with a little different process. The main layer of a perovskite solar cell is the absorber layer that is a perovskite organic-inorganic material. Bandgaps of this layer are almost in the range of 1.5-2.2 eV. This wide range helps perovskite solar cells to work in different wavelengths by changing the absorbers. The perovskite layer absorbs the photon illuminated from sunlight and then generates electron and hole pair due to the solid-state band theory and charge carrier's generation process. These charge carriers in the perovskite layer are separated by the employing of electron transport layer (ETL) and hole transport layer (HTL) and moved to the electrodes to generate the electric potential and current. These layers are demonstrated in Figure 1.

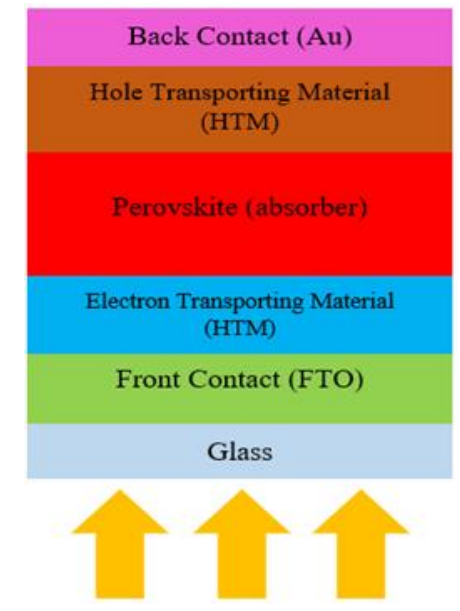

\section{Figure 1. Perovskite solar cell's general structure}

Perovskite solar cells are unique since they can be fabricated through different types of materials in each layer. For example, the general formula of the absorber layer is $\mathrm{MAX}_{3}$ that $\mathrm{M}$ is a monovalent cation that can be organic or inorganic cations like MA (methylammonium), FA (formamidinium), Cs, Rb, etc., A is a divalent cation like lead (II), tin (II), germanium (II), etc., and
$\mathrm{X}$ is a halide ion like iodine, chlorine, bromine. Utilizing each of these ions leads to different materials in this layer. Moreover, each of the hole transport layers and electron transport layers can be in organic, polymeric, and inorganic forms. Electron transport layers are usually in two organic (like fullerenes) and common inorganic $\left(\mathrm{TiO}_{2}, \mathrm{ZnO}, \mathrm{In}_{2} \mathrm{O}_{3}, \mathrm{SnO}_{2}\right.$, etc.) forms. Hole transport layers can find in three small molecules, polymer, and inorganic types. Spiro-OMeTAD is the most common HTL used in the perovskite solar cell structure that is a small molecule. It represented good efficiencies, but its high costs led to utilizing other forms like lowcost and high stability polymeric HTLs and inorganic HTLs [1].

We can find that each of these HTLs has some advantages and drawbacks. Therefore, using hybrid structures help the cell to have each type of HTLs' advantages, simultaneously. Hybrid structures in the perovskite solar cells' all layers refer to tandem, composite, etc. configurations. In the tandem one, two different types of the custom layer are deposited in continuous form. For example, two Spiro-OMeTAD and P3HT hole transport layers can be given in the structure instead of single Spiro-OMeTAD or P3HT, and this helps to efficiency increment and higher stability in some cases. The other important hybrid form for the layers is the composite form. In this configuration, in the desired layer two different materials with various compositions can be synthesized.

In 2017 ramli et al. simulated a tandem perovskite/siliconbased solar cell through the SCAPS-1D simulation program. The simulation was done for single silicon solar cells and tandem solar cells. Results represented that using tandem structure had a positive impact on the cell's efficiency and it was changed from almost $24 \%$ to $27 \%$ from single to tandem structure, respectively [2]. Another simulation was done in 2020 by Hossain et al. that utilized two perovskite absorbers including lead-free $\mathrm{Cs}_{2} \mathrm{AgBi}_{0.75} \mathrm{Sb}_{0.25} \mathrm{Br}_{6}$ and $\mathrm{CH}_{3} \mathrm{NH}_{3} \mathrm{SnI}_{3}$ absorber as upper and lower layers, respectively. The simulation was done in SCAPS$1 \mathrm{D}$ software and they achieved to improved efficiency of about $25 \%$ [3].

In this study, using different types and also different configurations of hole transport layers in a perovskite-based solar cell will be investigated via simulation tool for the first time. Three different HTLs including Spiro-OMeTAD as a small molecule, $\mathrm{P} 3 \mathrm{HT}$ as a polymer, and $\mathrm{Cu}_{2} \mathrm{O}$ as an inorganic one was chosen to compare them in three single, composite, and tandem configurations.

\section{Material and Method}

The structures mentioned above including various types of HTLs with different configurations were simulated in the SCAPS1D (Solar Cell Capacitance Simulator) simulation tool. It is a program specially developed for solar cells by Mark Burgelman at the Department of Electronics and Information Systems (ELIS) of the University of Gent, Belgium. It can give us information about charge recombination and their curve, I-V curve, and photovoltaic parameters containing VOC, JSC, FF, PCE [4]. In the mentioned perovskite-based structure, $\mathrm{Au}$ were employed as cathode (work function $=5.1 \mathrm{eV}$ ), FTO as anode (work function $=4.4 \mathrm{eV}$ ), $\mathrm{TiO}_{2}$ as the electron transport layer (thickness $=100$ $\mathrm{nm}$ ), and $\mathrm{CH}_{3} \mathrm{NH}_{3} \mathrm{PbI}_{3}$ as the absorber layer (thickness $=450 \mathrm{~nm}$ ), and three Spiro-OMeTAD, P3HT, $\mathrm{Cu}_{2} \mathrm{O}$ (thickness= $200 \mathrm{~nm}$ ) in the hybrid and single forms as the hole transport layer. 


\begin{tabular}{|c|c|c|c|c|c|}
\hline properties & $\mathrm{TiO}_{2}$ & $\mathrm{CH}_{3} \mathrm{NH}_{3} \mathrm{PbI}_{3}$ & P3HT & Spiro-OMeTAD & $\mathrm{Cu}_{2} \mathrm{O}$ \\
\hline Thickness (nm) & 100 & 450 & 200 & 200 & 200 \\
\hline bandgap (eV) & 3.2 & 1.5 & 1.05 & 3.06 & 2.17 \\
\hline electron affinity $(\mathrm{eV})$ & 3.9 & 3.9 & 3.9 & 2.05 & 3.2 \\
\hline $\begin{array}{c}\text { dielectric permittivity } \\
\text { (relative) }\end{array}$ & 9 & 30 & 3 & 3 & 7.11 \\
\hline $\begin{array}{c}C B \text { effective density of } \\
\text { states }\left(1 / \mathrm{cm}^{3}\right)\end{array}$ & $1.00 \mathrm{E}+19$ & $2.50 \mathrm{E}+20$ & $1.00 \mathrm{E}+20$ & $2.80 \mathrm{E}+19$ & $1.00 \mathrm{E} 17$ \\
\hline $\begin{array}{l}\text { VB effective density of } \\
\text { states }\left(1 / \mathrm{cm}^{3}\right)\end{array}$ & $1.00 \mathrm{E}+19$ & $2.50 \mathrm{E}+20$ & $1.00 \mathrm{E}+20$ & $1.00 \mathrm{E}+19$ & $1.00 \mathrm{E} 19$ \\
\hline $\begin{array}{c}\text { thermal velocity of } \\
\text { electron }(\mathrm{cm} / \mathrm{s})\end{array}$ & $1.00 \mathrm{E}+7$ & $1.00 \mathrm{E}+7$ & $1.00 \mathrm{E}+7$ & $1.00 \mathrm{E}+7$ & $1.00 \mathrm{E}+7$ \\
\hline $\begin{array}{l}\text { thermal velocity of hole } \\
(\mathrm{cm} / \mathrm{s})\end{array}$ & $1.00 \mathrm{E}+7$ & $1.00 \mathrm{E}+7$ & $1.00 \mathrm{E}+7$ & $1.00 \mathrm{E}+7$ & $1.00 \mathrm{E}+7$ \\
\hline $\begin{array}{c}\text { mobility of electron } \\
\left(\mathrm{cm}^{2} / V \mathrm{~s}\right)\end{array}$ & $2.00 \mathrm{E}+1$ & $5.00 \mathrm{E}+1$ & $1.00 \mathrm{E}-4$ & $1.00 \mathrm{E}-4$ & $5.00 \mathrm{E}+1$ \\
\hline $\begin{array}{l}\text { mobility of hole } \\
\left(\mathrm{cm}^{2} / V_{s}\right)\end{array}$ & $1.00 \mathrm{E}+1$ & $5.00 \mathrm{E}+1$ & $1.00 \mathrm{E}-4$ & $2.00 \mathrm{E}-4$ & $5.00 \mathrm{E}+1$ \\
\hline $\begin{array}{l}\text { dopant concentration of } \\
\text { donor } N_{D}\left(1 / \mathrm{cm}^{3}\right)\end{array}$ & $1.00 \mathrm{E}+16$ & 0 & 0 & 0 & 0 \\
\hline $\begin{array}{c}\text { dopant concentration of } \\
\text { acceptor } N_{A}\left(1 / \mathrm{cm}^{3}\right)\end{array}$ & 0 & $1.00 \mathrm{E}+17$ & $1.00 \mathrm{E}+18$ & $1.00 \mathrm{E}+18$ & $1.00 \mathrm{E}+18$ \\
\hline $\begin{array}{l}\text { Defect density } N t \\
\left(1 / \mathrm{cm}^{3}\right)\end{array}$ & 0 & $1.00 \mathrm{E}+13$ & 0 & 0 & 0 \\
\hline
\end{tabular}

Each of the utilized layers has its properties like their thicknesses and their charge amount.

SCAPS-1D simulates the custom solar cell by solving the essential Poisson and electron and hole continuity equations including these properties, simultaneously. The equations are given below:

$\vec{\nabla} \cdot \varepsilon \vec{\nabla} \varphi=-q\left(p-n+N_{D}+-N_{A^{-}}\right)$

$\vec{\nabla} \cdot \overrightarrow{J_{n}}=q(R-G)+q \frac{\partial n}{\partial t}$

$-\vec{\nabla} \cdot \overrightarrow{J_{p}}=q(R-G)+q \frac{\partial p}{\partial t}$

In these equations, $\varphi, \varepsilon, q, p, n, N_{D}, N_{A^{-}}, \overrightarrow{J_{p}}, \overrightarrow{J_{n}}, G, R$ are the electrostatic potential, dielectric permittivity, electric charge, hole density, electron density, the dopant concentration of donor, dopant concentration of acceptor, hole current density, electron current density, charge generation rate, recombination rate, respectively.

All of the needed parameters of the mentioned layers are given in Table 1.

In this study, three single, composite, and tandem configurations for the HTL were considered to compare the results. In the composite form, the thickness and dopant concentration of all samples were considered the same. In the tandem configuration, the thickness for each layer was considered as $100 \mathrm{~nm}$. Moreover, in the tandem state, each case was repeated in the inverted structure, too.
The simulation was performed at the temperature of $300 \mathrm{~K}$ and the sunlight angle of $48^{\circ}$ with the vertical line of the earth (A.M.1.5) and light power of $1000 \mathrm{~W} / \mathrm{m} 2$.

\section{Results and Discussion}

The simulation was done in the mentioned conditions and the results are represented in this section. The results were given in the following sections as the single, composite, tandem forms, and final I-V curve.

\subsection{Comparison of HTLs in a single form}

In the first step, the best candidates of the three mentioned categories for HTLs including Spiro-OMeTAD, P3HT, and $\mathrm{Cu}_{2} \mathrm{O}$ were chosen and their results were compared. Results indicated that the best performance was obtained for $\mathrm{Cu}_{2} \mathrm{O}$ with $19.77 \%$ efficiency compared to $19.26 \%$ and $15.92 \%$ for Spiro-OMeTAD and P3HT, respectively. Figure 2 illustrates the comparison of these three single HTLs in the perspective of photovoltaic parameters. 

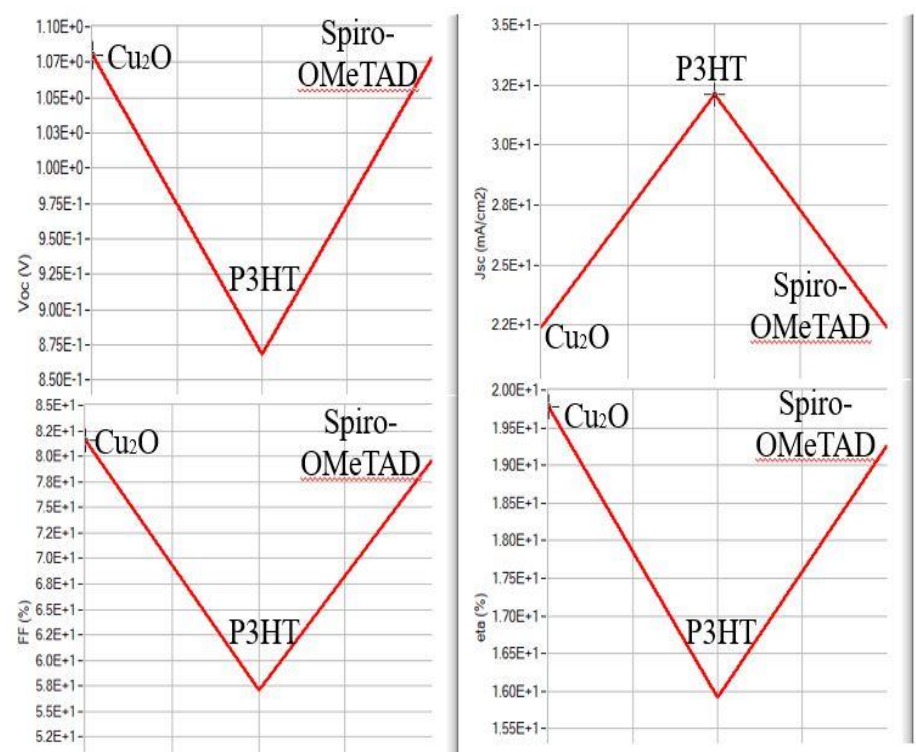

Figure 2- Photovoltaic parameters for the single HTLs

\subsection{Comparison of HTLs in composite form}

In this step, three composite configurations were simulated with the use of Spiro-OMeTAD, P3HT, $\mathrm{Cu}_{2} \mathrm{O}$ as HTLs two by two with each other. In each composite including SpiroOMeTAD/P3HT, Spiro-OMeTAD/Cu2O, and P3HT/ $/ \mathrm{Cu}_{2} \mathrm{O}$, the composition of each single HTM can be varied from 0 to 1 . Here, each composite was optimized from the view of the composition of HTLs. Results represented that the optimum composition for the material in Spiro-OMeTAD/P3HT, Spiro-OMeTAD/ $\mathrm{Cu}_{2} \mathrm{O}$, and $\mathrm{P} 3 \mathrm{HT} / \mathrm{Cu}_{2} \mathrm{O}$ composites were $0.1 / 0.9,0 / 1,0.6 / 0.4$, with the efficiencies of $24.57 \%, 19.77 \%$, and $20.66 \%$, respectively. Figure 3 (a-c) displays the variation of photovoltaic parameters with the change of composition of HTLs in each composite configuration.
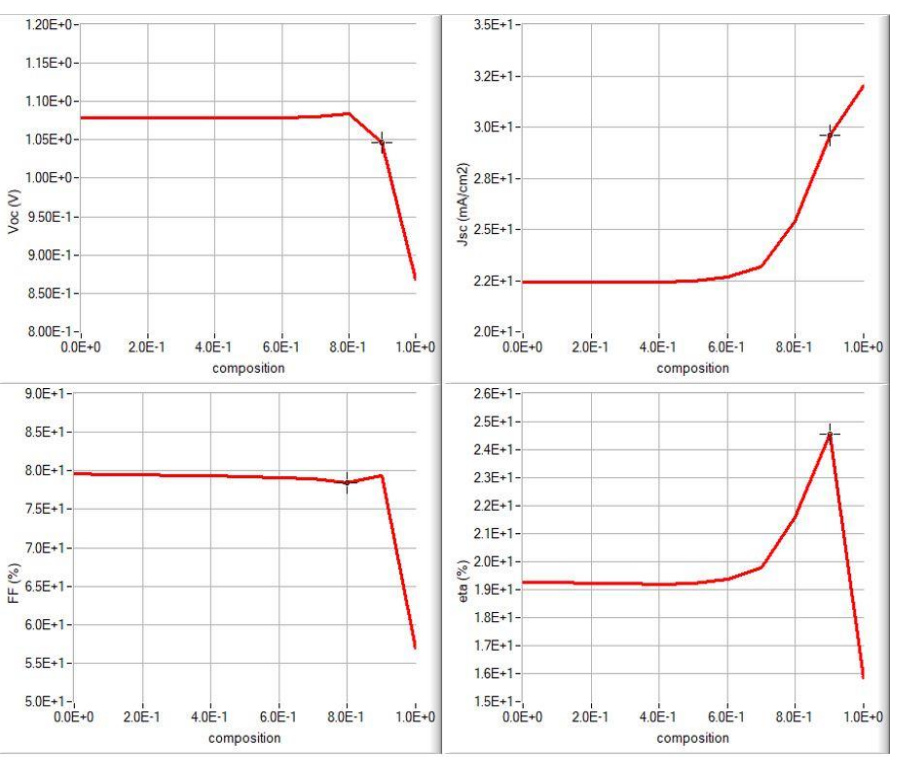

Figure 3-a. Photovoltaic parameters vs. composition of P3HT in the Spiro-OMeTAD/P3HT composite
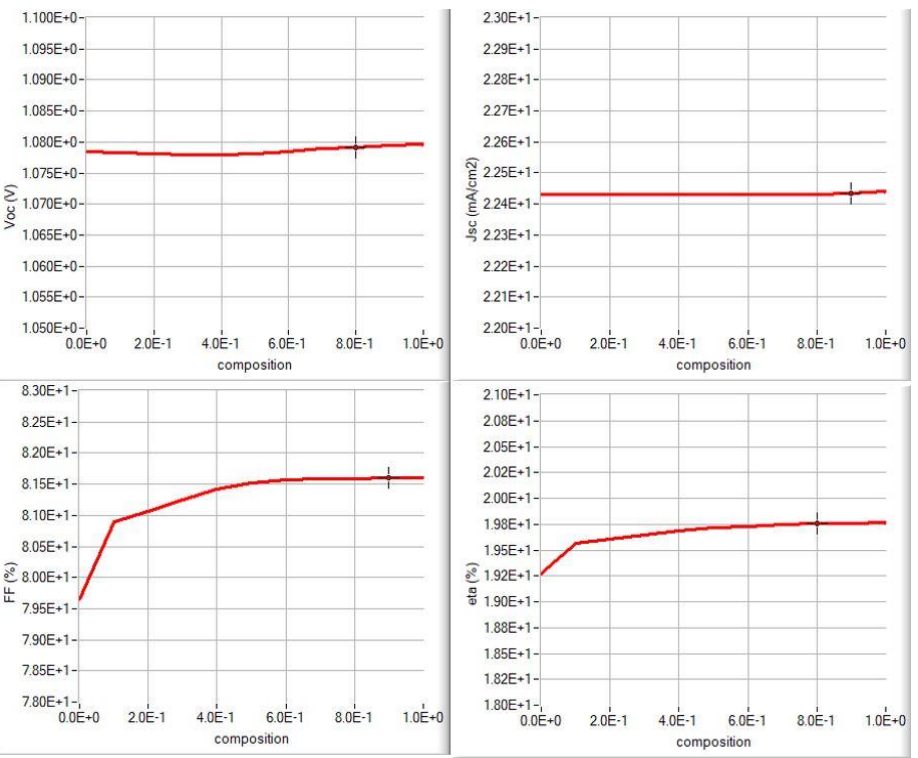

Figure 3-b. Photovoltaic parameters vs. composition of $\mathrm{Cu}_{2} \mathrm{O}$ in the Spiro-OMeTAD/Cu $\mathrm{O}_{2} \mathrm{O}$ composite
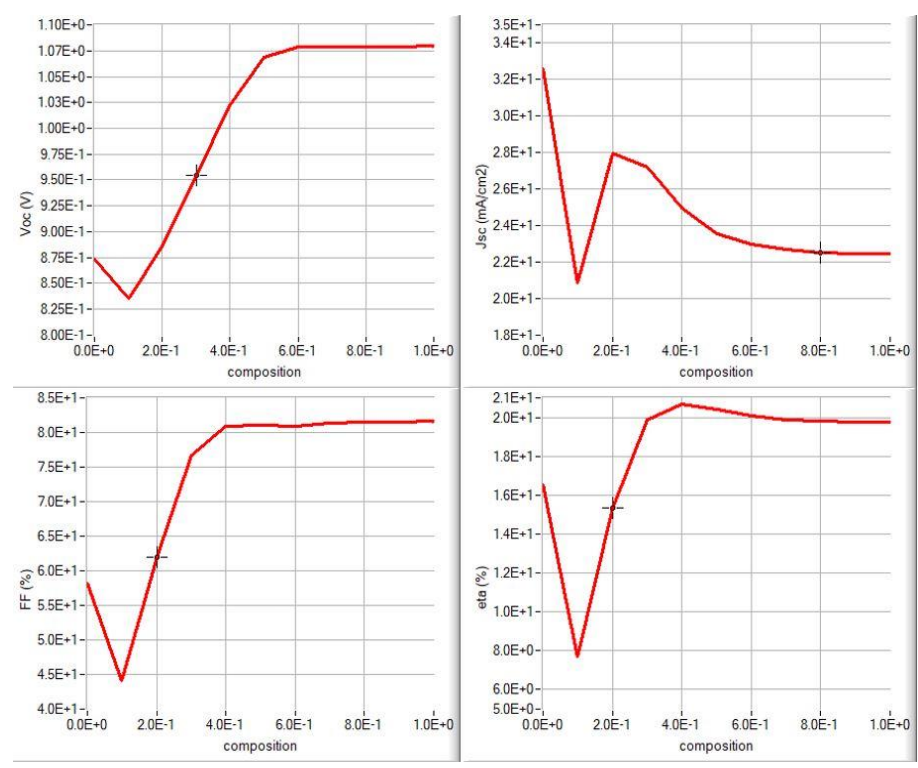

Figure 3-c. Photovoltaic parameters vs. composition of $\mathrm{Cu}_{2} \mathrm{O}$ in the $\mathrm{P} 3 \mathrm{HT} / \mathrm{Cu}_{2} \mathrm{O}$ composite

\subsection{Comparison of HTLs in tandem form}

In this form, the mentioned HTLs were placed in continuous and series configuration named as tandem structure. In this section, all of the possible cases of HTLs' tandem configurations were simulated and their results were investigated. The cases include Spiro-OMeTAD/Spiro-OMeTAD (or single SpiroOMeTAD), Spiro-OMeTAD/P3HT, Spiro-OMeTAD/ $\mathrm{Cu}_{2} \mathrm{O}$, P3HT/ Spiro-OMeTAD, P3HT/P3HT (or single P3HT), $\mathrm{P} 3 \mathrm{HT} / \mathrm{Cu}_{2} \mathrm{O}, \quad \mathrm{Cu}_{2} \mathrm{O} / \quad$ Spiro-OMeTAD, $\mathrm{Cu}_{2} \mathrm{O} / \mathrm{P} 3 \mathrm{HT}$, and $\mathrm{Cu}_{2} \mathrm{O} / \mathrm{Cu}_{2} \mathrm{O}$ (or single $\mathrm{Cu}_{2} \mathrm{O}$ ) with $100 \mathrm{~nm}$ thickness for all HTLs (the first HTLs mentioned here, refer to the layer near the electrode). Results showed that $\mathrm{Cu}_{2} \mathrm{O} / \mathrm{P} 3 \mathrm{HT}$ and SpiroOMeTAD/P3HT tandem structures represent better performance with efficiencies of about $27 \%$ compared to other structures. 
Figure 4 confirms these results in the form of power conversion efficiency.

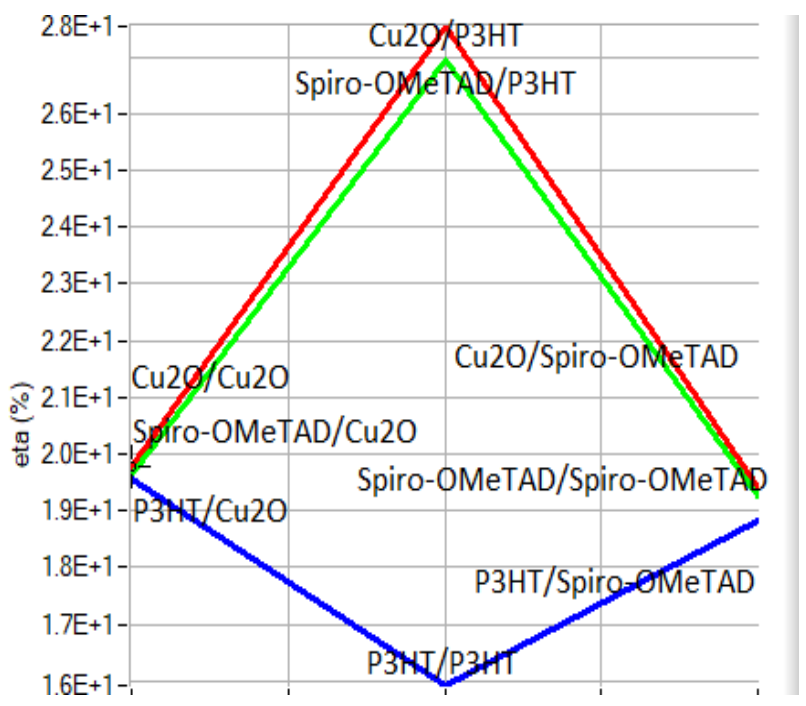

Figure 4- Efficiency of all tandem HTL structures

\subsection{Final I-V curve}

With the comparison of all configurations mentioned above, it can be understood that the best efficiency among all structures belongs to the type of tandem HTL cells that the P3HT layer was placed between the upper HTL near the electrode and the absorber layer. This could be because of the structural modification role of P3HT layer. However, these implementations were demonstrated in figure $5(\mathrm{a}, \mathrm{b})$ and table 2 . The results were in good agreement with experimental works, too [8-11].

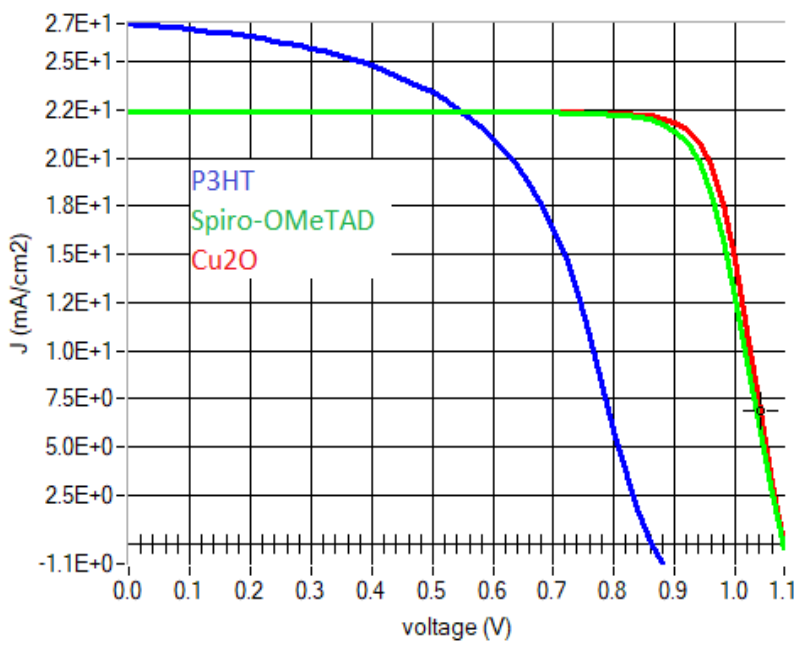

Figure 5-a. Current-density (I-V) curve of different HTLs in the single configuration

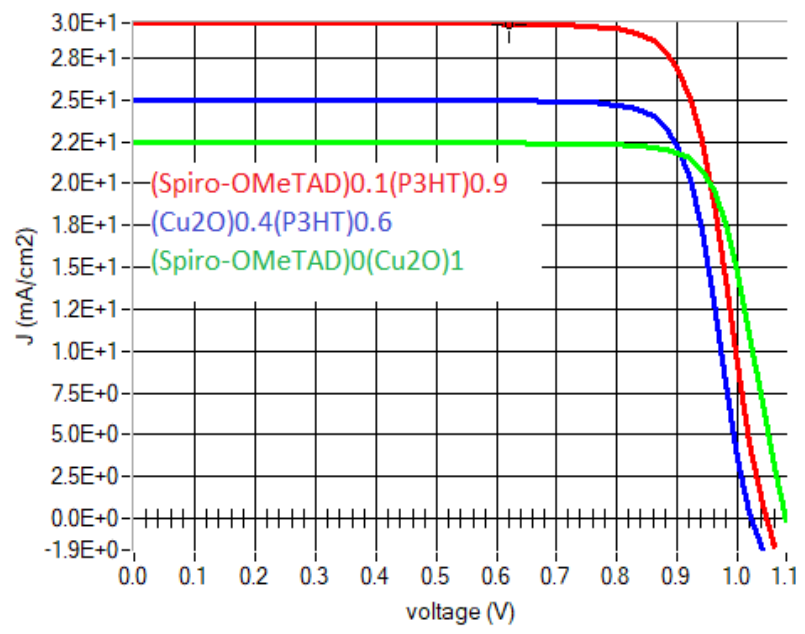

Figure 1-b. Current-density (I-V) curve of different composite HTLS

Table 2- Photovoltaic parameters of configurations used for HTLs

\begin{tabular}{|c|c|c|c|c|c|c|c|c|c|}
\hline configuration & HTL & \multicolumn{2}{|c|}{$\mathbf{V}_{\text {OC }}$} & \multicolumn{2}{|c|}{$\mathbf{J}_{\mathrm{SC}}$} & \multicolumn{2}{|c|}{ FF } & \multicolumn{2}{|c|}{ PCE } \\
\hline \multirow{3}{*}{ simple } & Spiro-OMeTAD & $\begin{array}{c}1.08 \\
\text { (SCAPS) }\end{array}$ & $\begin{array}{l}0.98 \\
(\exp )\end{array}$ & $\begin{array}{c}22.43 \\
\text { (SCAPS) }\end{array}$ & $\begin{array}{l}21.20 \\
(\exp )\end{array}$ & $\begin{array}{c}79.63 \\
\text { (SCAPS) }\end{array}$ & $\begin{array}{l}77.60 \\
(\exp )\end{array}$ & $\begin{array}{c}19.26 \\
\text { (SCAPS) }\end{array}$ & $\begin{array}{l}18.7 \\
(\exp )\end{array}$ \\
\hline & P3HT & $\begin{array}{c}0.87 \\
\text { (SCAPS) }\end{array}$ & $\begin{array}{l}0.80 \\
(\exp )\end{array}$ & $\begin{array}{c}32.09 \\
\text { (SCAPS) } \\
\end{array}$ & $\begin{array}{l}19.20 \\
(\exp )\end{array}$ & $\begin{array}{c}57.09 \\
\text { (SCAPS) } \\
\end{array}$ & $\begin{array}{l}73.30 \\
(\exp )\end{array}$ & $\begin{array}{c}15.92 \\
\text { (SCAPS) } \\
\end{array}$ & $\begin{array}{l}15.4 \\
(\exp )\end{array}$ \\
\hline & $\mathrm{Cu}_{2} \mathrm{O}$ & $\begin{array}{c}1.08 \\
\text { (SCAPS) }\end{array}$ & $\begin{array}{l}0.99 \\
(\exp )\end{array}$ & $\begin{array}{c}22.44 \\
\text { (SCAPS) }\end{array}$ & $\begin{array}{l}19.70 \\
(\exp )\end{array}$ & $\begin{array}{c}81.60 \\
\text { (SCAPS) }\end{array}$ & $\begin{array}{l}75.00 \\
(\exp )\end{array}$ & $\begin{array}{c}19.77 \\
\text { (SCAPS) }\end{array}$ & $\begin{array}{l}18.4 \\
(\exp )\end{array}$ \\
\hline \multirow{3}{*}{ composite } & $\begin{array}{c}\text { (Spiro- } \\
\text { OMeTAD })_{0.1}(\mathrm{P} 3 \mathrm{HT})_{0.9} \\
\end{array}$ & \multicolumn{2}{|c|}{1.05} & \multicolumn{2}{|c|}{29.59} & \multicolumn{2}{|c|}{79.37} & \multicolumn{2}{|c|}{24.57} \\
\hline & $\begin{array}{c}\text { (Spiro- } \\
\text { OMeTAD })_{0}\left(\mathrm{Cu}_{2} \mathrm{O}\right)_{1}\end{array}$ & \multicolumn{2}{|c|}{1.08} & \multicolumn{2}{|c|}{22.44} & \multicolumn{2}{|c|}{81.60} & \multicolumn{2}{|c|}{19.77} \\
\hline & $\left(\mathrm{Cu}_{2} \mathrm{O}\right)_{0.4}(\mathrm{P} 3 \mathrm{HT})_{0.6}$ & \multicolumn{2}{|c|}{1.02} & \multicolumn{2}{|c|}{25.00} & \multicolumn{2}{|c|}{80.84} & \multicolumn{2}{|c|}{20.66} \\
\hline \multirow{3}{*}{ tandem } & $\begin{array}{c}\text { Spiro- } \\
\text { OMeTAD/P3HT } \\
\end{array}$ & \multicolumn{2}{|c|}{1.09} & \multicolumn{2}{|c|}{31.47} & \multicolumn{2}{|c|}{78.37} & \multicolumn{2}{|c|}{26.97} \\
\hline & $\begin{array}{l}\text { P3HT/Spiro- } \\
\text { OMeTAD }\end{array}$ & \multicolumn{2}{|c|}{1.08} & \multicolumn{2}{|c|}{22.43} & \multicolumn{2}{|c|}{77.86} & \multicolumn{2}{|c|}{18.81} \\
\hline & $\begin{array}{c}\text { Spiro- } \\
\text { OMeTAD } / \mathrm{Cu}_{2} \mathrm{O}\end{array}$ & \multicolumn{2}{|c|}{1.08} & \multicolumn{2}{|c|}{22.44} & \multicolumn{2}{|c|}{81.03} & \multicolumn{2}{|c|}{19.63} \\
\hline
\end{tabular}




\section{Conclusions and Recommendations}

Recently, the usage of newly developed perovskite solar cells has experienced rapid improvements because of their tremendous features. Perovskite solar cells consist of several layers that each one has its specific role in the cell structure. In this study, the hole transport layer with different configurations in a perovskite-based solar cell was investigated. Results represented that developing new structures like composite forms and tandem configurations, significantly lead to efficiency increment in the cell. The best structure for the custom cell used in this study obtained about $27 \%$ for the $\mathrm{Cu}_{2} \mathrm{O} / \mathrm{P} 3 \mathrm{HT}$ tandem structure.

\section{Acknowledge}

The authors would like to thank the cooperation of the university of Tabriz, the University of Sakarya.

\section{Funding}

The authors have no received any financial support for the research, authorship, or publication of this study.

\section{The Declaration of Conflict of Interest/ Common Interest}

This study was produced from the Seyyed Reza Hosseini, Master thesis which was accepted on April 14, 2021, in the Department of Chemical Engineering, the University of Tabriz with supervisor Prof. Aligholi Niaei and advisor Ass. Prof. Dr. Nagihan Delibaş.

\section{References}

[1] Hussain, I., Tran, H. P., Jaksik, J., Moore, J., Islam, N., \& Uddin, M. J. (2018). Functional materials, device architecture, and flexibility of perovskite solar cell. Emergent Materials, 1(3), 133-154.

[2] Ramli, N. F., Sepeai, S., Rostan, N. F. M., Ludin, N. A., Ibrahim, M. A., Teridi, M. A. M., \& Zaidi, S. H. (2017, May). Model development of monolithic tandem silicon-perovskite solar cell by SCAPS simulation. In AIP Conference Proceedings (Vol. 1838, No. 1, p. 020006). AIP Publishing LLC.

[3] Hossain, A., Hasan, M. M., Rahman, M. S., \& Hossain, M. M. (2020, June). Fully Lead-Free All Perovskite Tandem Solar Cell with Improved Efficiency: Device Simulation Using SCAPS-1D. In 2020 IEEE Region 10 Symposium (TENSYMP) (pp. 1221-1224). IEEE.

[4] Burgelman, M., Nollet, P., \& Degrave, S. (2000). Modelling polycrystalline semiconductor solar cells. Thin solid films, 361, 527-532.

[5] Karimi, E., \& Ghorashi, S. M. B. (2017). Investigation of the influence of different hole-transporting materials on the performance of perovskite solar cells. Optik, 130, 650-658.

[6] Karimi, E., \& Ghorashi, S. M. B. (2017). Simulation of perovskite solar cell with P 3 HT hole-transporting materials. Journal of Nanophotonics, 11(3), 032510.

[7] Kim, E., \& Bhattacharya, I. (2020, June). Material selection method for a perovskite solar cell design based on the genetic algorithm. In 2020 47th IEEE Photovoltaic Specialists Conference (PVSC) (pp. 2631-2634). IEEE.

[8] Zhang F, Shi W, Luo J, Pellet N, Yi C, Li X, Zhao X, Dennis TJ, Li X, Wang S, Xiao Y. (2017) "Isomer-pure bis-PCBMassisted crystal engineering of perovskite solar cells showing excellent efficiency and stability", Advanced Materials, vol. 29(17), 1606806.

[9] Kapur, V. K., Basol, B. M., \& Tseng, E. S. (1987). Low cost methods for the production of semiconductor films for CuInSe2/CdS solar cells. Solar cells, 21(1-4), 65-72.

[10] Kapur, V. K., Bansal, A., Le, P., \& Asensio, O. I. (2003). Nonvacuum processing of CuIn1- $\mathrm{xGaxSe} 2$ solar cells on rigid and flexible substrates using nanoparticle precursor inks. Thin solid films, 431, 53-57.

[11] Dhere, N. G., Ghongadi, S. R., Pandit, M. B., Jahagirdar, A. H., \& Scheiman, D. (2002). CIGS2 thin-film solar cells on flexible foils for space power. Progress in Photovoltaics: Research and Applications, 10(6), 407-416. 